\title{
DISTRIBUTION AND PALAEOENVIRONMENTAL SIGNIFICANCE OF THE GENUS BOUCHARDIA (BRACHIOPODA, TEREBRATELLIDINA): ITS BEARING ON THE CENOZOIC EVOLUTION OF THE SOUTH ATLANTIC
}

\author{
MIGUEL O. MANCEÑIDO* and MIGUEL GRIFFIN*
}

\begin{abstract}
A reappraisal of available information concerning fossil species of the genus Bouchardia Davidson 1850 reveals occurrences in various stratigraphic units ranging from about the uppermost Cretaceous-Palaeocene boundary to the Mio-Pliocene. Whereas the genus has not been reported from certain late Tertiary marine units of southern Patagonia, it does survive to the present in Brazilian seas. The geographical distribution of confirmed records is displayed in palaeocontinental reconstruction maps. Thus a conspicuous latitudinal displacement in a northwards direction along the eastern (Atlantic) margin of South America becomes apparent. Furthermore, typical environmental conditions and autecological features known for the only living species, B. rosea (Mawe), include an apically counterweighted shell well suited for free lying on a clean, coarse-grained sedimentary bottom in platform and coastal areas, with maximum abundance achieved in euhaline, nutrient-rich waters, 18 to $26 \mathrm{~m}$ deep, ideally between $20^{\circ}-22^{\circ} \mathrm{C}$. On the assumption that the above mentioned ecological requirements have remained approximately the same throughout the Cenozoic for congeneric species, which do show similar skeletal adaptations and taphonomic evidences, the following conclusions can be drawn: (1) During the Palaeogene the shallow waters along the coasts of southern Patagonia and the Antarctic Peninsula should have reached significantly warmer temperatures than those presently recorded in the same region; (2) In Neogene times, the southern limit for such relatively high temperature levels in the shallow waters of the western South Atlantic shores seems to have been progressively displaced towards more northerly zones as reflected by the brachiopod migration; (3) In the context of known geotectonic events and their inferred palaeoceanographic consequences, the opening of the Drake Passage and the resulting establishment of the circum-polar Antarctic current system, is suggested as the most likely triggering factor. This caused a major rearrangement of the oceanic circulation pattern and a widespread cooling in the area as well, eventually leading to the withdrawal of representatives of Bouchardia to the more restricted present day distribution held by extant propulations. As a complement to the study, selected illustrative specimens are figured.
\end{abstract}

RESUMO Uma revisão dos dados disponíveis de espécies fósseis do gênero Bouchardia Davidson 1850 revela sua ocorrência em várias unidades estratigráficas desde aproximadamente a passagem do final do Cretáceo para o Paleoceno, até o Mio-Plioceno. Se, por um lado, o gênero não tem sido descrito em certas unidades marinhas do Terciário Superior do Sul da Patagônia, por outro, ele sobrevive atualmente em mares brasileiros. Os registros confirmados em mapas paleogeográficos revelam um desiocamento para norte ao longo da margem oriental (Atlântica) da América do Sul. As condições ambientais e feições autoecológicas conhecidas das únicas espécies viventes $(B$. rosea Mawe) incluem uma concha contrabalanceada em região apical, adequada para repousar livremente em fundos sedimentares de granulação grossa e limpos, em plataformas e áreas costeiras. A abundância máxima é atingida em águas hialinas, ricas em nutrientes, em profundidades de 18 a $26 \mathrm{~m}$ e idealmente sob temperaturas de $20-22^{\circ} \mathrm{C}$. Admitindo-se que através do Cenozóico estes requisitos ecológicos tenham permanecido aproximadamente iguais, para espécies congêneres, com adaptações estruturais e evidências taxonômicas similares, pode-se concluir que: (1) Durante o Paleogeno as águas rasas ao longo da costa sul da Patagônia e Península Antártica devem ter atingido temperaturas mais mornas que as registradas atualmente na região; (2) durante o Neogeno, esse limite sul de níveis de temperatura relativamente altos em águas rasas parecem ter-se deslocado progressivamente para zonas mais setentrionais, como sugere a migração de braquiópodes; (3) ao se inserir essas interpretações no contexto dos eventos geotectônicos conhecidos e suas consequiências paleoceanográficas, a abertura da Passagem de Drake e o estabelecimento resultante do sistema antártico de correntes circum-polares são sugeridos como os fatores mais intrigantes. Isso causou um rearranjo no padrão de circulação e um resfriamento generalizado da área, eventualmente levando à remoção de representantes de Bouchardia para a distribuição atual mais restrita. Como um complemento do estudo, ilustram-se alguns espécimes selecionados.

"(...) I have only intended to show that fossils may no more be regarded as mere dead-born medals, but must always be looked upon as the remains of living beings, the existence of which depended upon a thousand external conditions." Edward SUESS (1860, p. 293)

INTRODUCTION Bouchardia is a very peculiar but rather neglected genus of terebratulide brachipods comprising a single living species of fairly small size, in addition to a handful of fossil relatives that demonstrate a more or less continuous record extending back to the very dawn of Tertiary times. As early as 1850 , it was named after a 
French naturalist by a British scientist, Thomas Davidson, whose skillful original illustrations depicting its characteristic internal features have remained unsurpassed for more than a century (cf. Davidson 1850, Pl. 1, Fig. 1-6, Richardson 1973, Pl. 7, Fig. 8). It has since become the type-genus of a most remarkable southem hemisphere terebratellidine subfamily, the Bouchardiinae Allan 1940, which has been revised independently in a couple of papers by Levy (1964) and by Richardson (1973) respectively based upon Argentinean and Australasian materials, and thus, albeit partial, somewhat complementary in their scope.

With regard to its palaeogeographical significance, the author who probably accomplished the most extensive knowledge of this genus for his time was Hermann von Thering. He only touched the subject incidentally (Thering 1903 , p. 341,1907, p. 473,1927, p. 96 ) to point out the inferred Magellanian origins of Bouchardia, that it persisted along the Argentine coasts through most of the Tertiary, allegedly to the Recent when it reached the Brazilian and adjacent seas as well, and he also thought that Eocene Patagonian waters would have heen warner than nowadays. Such a statement was echoed by subsequent authors, i.e.: Thomson (1918, p. 262.263), Windhausen (1931, p. 369 , 446) or Martins (1952, p. 4). Thering's remarks, however, are so brief and broad, that it is not altogether clear whether he actually meant a proper displacement of its entire geographical extent with abandonment of former area (i.e.: metachoresia sensu Termier \& Termier 1956) or else just an expansion of its former range retaining occupation of previous area (i.e.: prochoresia sensu Termier \& Termier op. cit.).

Having added a few new records from own field-work, it was soon realized that valuable information was rather dispersed in the palaeontological and biological literature, and sometimes flawn with inadvertent inaccuracies of various sorts. Therefore it seemed worthwhile to try to assemble these scattered data so as to provide a comprehensive picture of the genus in space and time, in order to ascertain which kind of migration is more likely to have taken place and what is its relevance, if any, for the Cenozoic evolution of the South Atlantic.

DISTRIBUTION A suitable arrangement according to temporal, taxonomical, and geographical criteria has been followed in this account, in order to present the information gathered from the relevant literature, Argentine Museum collections and own observations in an orderly and readily understandable fashion. Thus, in reviewing the various stratigraphic units yielding fossil Bouchardia species, attention has been duly paid to incorporate currently accepted ages based on independent evidence as far as possible, and these records are conveniently treated and displayed in groups, namely: Palaeogene, Neogene and Recent (Figs. 1-3). To carry out the geographical plotting a set of palaeocontinental reconstruction maps has been chosen from Smith \& Briden's (1977) reassemblies. The south polar stereographic projection has been favoured as being more meaningful to the nature of the data to be depicted, and the equal-interval sequence of present-day, $20 \mathrm{Ma}$ and $40 \mathrm{Ma}$ ago, were somewhat arbitrarily taken to represent the above mentioned epochs concerned.

It should be made clear at this point that certain nominal species originally assigned to Bouchardia (such as B. patagonica Thering 1903, B. minima Thomson 1918, or $B$. rhizoida Hutton 1905 etc.) which have been subsequently transferred to other genera (i.e.: Bouchardiella, Neobouchardia, Rhizothyris) are not dealt with in this paper.

Paleogene records - The oldest Bouchardia reported so far corresponds to B. conspicua Feruglio (1935 p. 87, 1936/37 p. 96-98, Pl. 11, Fig. 5-10). His illustrated specimens come from outcrops in Santa Cruz province, on both the northern (Río Leona) and southern (Arroyo Calafate) shores of Lago Argentino. These brachiopod-bearing beds, originally regarded as Senonian by Feruglio $(1935,1936 / 37)$, were subsequently referred by him $(1938$ p. $315-331,1944$ p. 59-86) to the Danian (uppermost Cretaceous by then). From a lithostratigraphical viewpoint, they were recognized by Feruglio as a conspicuous horizon on top of the Calafate Beds (for the southern outcrops), and the new term Man Aike Sandstones or Beds was coined for the northern ones, yet clearly indicating at the same time that they were equivalent (cf. Feruglio 1949, I p. 269-276, with additional fossiliferous locatities in the Shehuen valley, Lago Cardiel region).

Confirmatory longitudinal serial sections were published by Levy (1964 p. 215, Pl. 2, Fig. 8-26) on the basis of specimens collected from the neighbourhoods of Lago Argentino by Furque. She gave the stratigraphical provenance as "Salamanquense (Paleoceno)", whereas in Furque's (1973 p. 33) geological description, the species was mentioned under both the Man Aike and Calafate Formations (Upper Maastrichtian). More recently it was listed by Riccardi \& Rolleri (1980 p. 1231) among the representative fossils of the Man Aike Formation, which probably belongs into a Maastrichtian-Palaeocene age. Having had access to their material (PI. 1, Fig. 16), also from the southern shore of Lago Argentino (near Puesto Estancia 25 de Mayo), the record has been further substantiated, especially with regard to the remarkable size-range and outline variability exhibited, as well as the nature of the surrounding sediments (i.e.: a medium-grained, greenish-gray, slightly friable calcareous sandstone).

Similar forms occur further south, in Río Guillermo, to the west of Estancia Cancha Carreras (Santa Cruz), as reported by Hünicken (1955 p. 131-132), from the upper section of "Estratos del Cerro Dorotea" (= "Capas con Ostrea rionegrensis" = Cerro Dorotea Formation), thus also of comparable age (cf. Riccardi \& Rolleri 1980 p. 1194, 1232).

- The species Bouchardia exigua Camacho 1949 has been described from two nearby localities just north and ENE of Laguna Rio Bueno, eastern Tierra del Fuego (Furque \& Camacho 1949 p. 279, P1. 1, Fig. 6), and a paratype was later longitudinally serial sectioned by Levy (1964 p. 215 , PI. 2, Fig. 1-7). All the material comes from a stratigraphical unit initially named as "Estratos de Rio Bueno" and dated as Danian (uppermost Creataceous by then), but lately known as Rio Bueno Formation, which has been consistently regarded as Palaeocene in age (Camacho 1967 b p. $258-260$, Caminos 1980 p. 1470,1488 ).

- Geologically younger, but the earliest to be described as fossil, is B. zitteli Thering (1897 p. 268-270, text-Fig. 6) which occurs abundantly around the San Julian area in Santa Cruz. Additional figures were provided by Thering (1903 p. 334, P1. 3, Fig. 10, see also Doello-Jurado 1922 p. 198). Specimens from Gran Bajo de San Julian, showing 


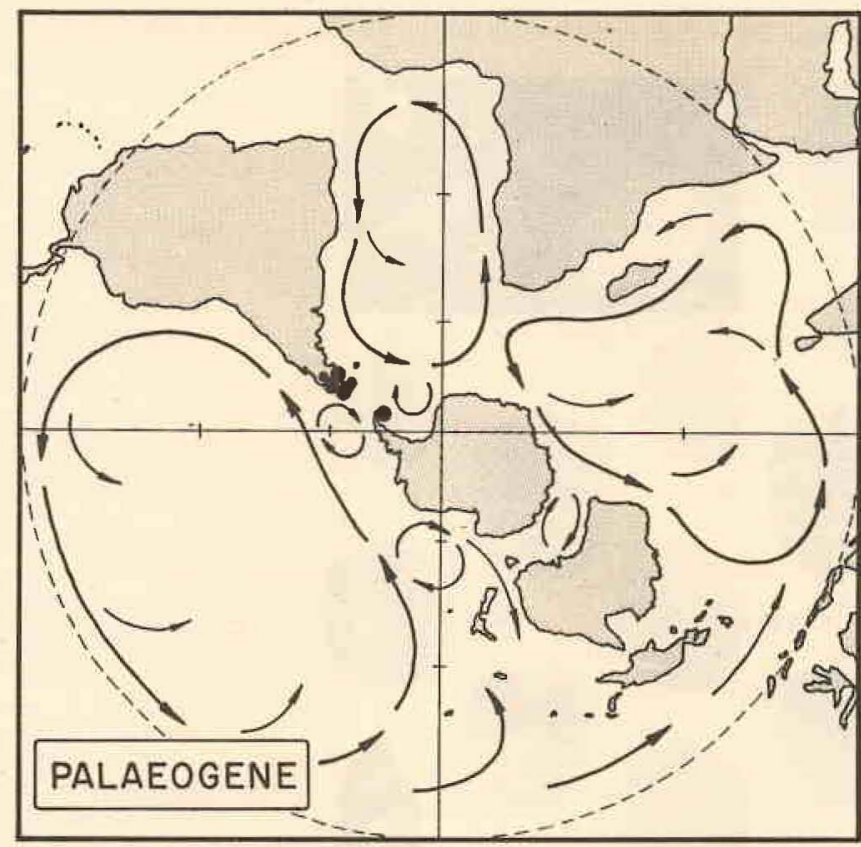

Figure 1 -Distribution of Bouchardia during the Palaeogene. Relative position of continents after Smith \& Briden (1977, p. 41), southern hemisphere oceanic circulation pattern compiled and tentative. Each black dot represents up to three nearby fossiliferous localities and a larger black circle signifies a cluster of localities comprising no less than four individual sites

the interior, were illustrated by Levy (1964 p. 214-215, Pl. 1, Fig. 34), and material collected by Gaggero from Punta Cuevas is herein figured for the first time (P1. 1, Photo 8), alongside with other from Pão de Açúcar and Manantial Salado (Ihering's collection).

Occurrence of this species further west, in the Rio Tarde section, near Lago Pueyrredón was documented by Ortmann (1902 p. 79-80, Pl. 13, Fig. 9a-b) and also reported by Hatcher (1900 p. 101-102), Thering (1903 p. 334, 1907 p. 480), and Feruglio (1949, II p. 127).

Shells from the San Julian region occur in pale yellowish-gray, very friable, medium- to coarse-grained, slightly calcareous sandstones.

The stratigraphical provenance is consistently recorded as "Patagónico inferior" (Lower Patagonian) or "Juliense" (cf. Ihering 1903, 1907, 1914, Ortmann 1902 p. 278, Feruglio 1949, II p. 111,252 , Levy 1964 p. 215). That means the San Julian Formation or the San Julian Member of the Patagonia Formation of modern usage (cf. Bertels 1970, Riggi 1978, 1979), whose fauna was formerly held as either Eocene (Ihering 1907 p. 72,1914 p. 133), early Miocene (Ortmann 1902 p. 293, 303), or late Oligocene-early Miocene (Hatcher 1900 p. 103-104, Feruglio op. cit., II p. 271-272), but is nowadays regarded as mid to late Eocene (up to early Oligocene) in age (Bertels 1975 p. 434-439, 1979 p. 310-314, Zinsmeister 1981 p. 1090). - On the basis of material obtained by Nordenskjöld's South Polar Expedition from off Graham Land, Antarctica, Buckman (1910 p. 14-17, Pl. 1, Fig. 1-6b, Pl. 3, Fig. 2a-b) described five nominal species, namely, $B$. ovalis, $B$. antarctica, $B$. angusta, $B$. elliptica, and $B$. attenuata. The age of the so called "Seymour Island Younger Beds" was interpreted as Pliocene-Miocene by Buckman (1910 p. 31-35) or late Miocene by Thomson (1918 p. 260). More recently, further collecting by various parties (i.e.: British Antarctic Survey, Ohio Institute of Polar Studies, Argentine Antarctic Institute, and La Plata Museum) has confirmed the existence of numerous fossiliferous localities around the NE end of Isla Marambio (= Seymour Island). A suite of nearly 200 specimens was revised by Owen (1980 p. 132-135, text-Fig. 17-26b), who produced the first stereoscopic photographs and bivariate scatter diagrams supporting his view that all Buckma's "species" represent in fact subjective synonyms of a single variable species assignable to $B$. antarctica.

A considerable range in overall morphology and size is also recognizable among La Plata Museum specimens (Pl. 1, Photos 11-12), and their surroundings matrix varies from medium - to coarse-grained, greenish to pale gray, fairly consolidated to easily friable, sometimes glauconitic, sometimes micaceous sandstones. These rocks belong to the upper unit of the Seymour Island Series or Group, ie.: the La Meseta Formation of the current scheme, which is presently referred to the late Eocene-early Oligocene (cf. Cione et al. 1977 p. 6-8, Cione 1979 p. 194-195, Zinsmeister \& Camacho 1980 p. 2, 12, Feldmann \& Zinsmeister 1984 p. 1047-1048, Tonni \& Cione 1979 p. 73-74, as "Marambío" Formation).

- Reports concerning presumably new species are also known for the Rio Turbío coal-field district. So far they have only been mentioned by Brandmayr (1945 p. 429). and Hünicken $(1955$ p. $36,38,85,111,120)$ from the upper course of the Río Turbio (lower section of the "Magellanian" Beds) and from Sierra Dorotea-Vega San José (Río Turbío Beds) respectively. Personal sampling has yielded additional specimens from several horizons which are herein figured to provide confirmatory evidence (Pl. 1, Photos 13-15). A cardinalium typical for the genus had been recognized already by Hünicken (personal communication) by means of unpublished serial sections. The usual lithology for the Sierra Dorotea occurrences is a mediumto coarse-grained, light greenish to yellowish-gray, moderately consolidated, often decalcified sandstone, whereas Brandmayr's "a level" corresponds to a more friable, dark gray to greenish sandstone, medium- to coarse-grained with small round pebbles interspersed.

All these brachiopod-bearing beds thus belong to the Rio Turbío Formation which supersedes older equivalent terms (such as "Magallanense marino" or "Estratos de Rio Turbio") and is mostly attributed to the mid and late Eocene (Riccardi \& Rolleri 1980 p. 1233-1236).

Neogene Records A characteristic form rather widespread in subsurface deposits of the Pampean plains is Bouchardia transplatina, which was originally described by Ihering (1907 p. $356,480-481$, Pl. 18, Fig. 131a-b) from a well in the outskirts of Buenos Aires: Puente Alsina, Barracas al Sud, at a depth of $75 \mathrm{~m}$, and later reillustrated by Camacho (1967a p. 51-52, P1. 8, Fig. 4a-d) and herein (P1. 1, Photos 3-4). It was additionally recovered, again from water supply wells in Buenos Aires province, by Doello-Jurado (1922 p. 197-198, cf. also 1915 p. 592-593) near Arroyo del Pescado, between La Plata and Magdalena, at a depth of about $90 \mathrm{~m}$, and also by Carral Tolosa (1942 p. 566) in Monte Veloz, about $10 \mathrm{~km} \mathrm{SW}$ of Punta Piedras, at greater depths $(365-380 \mathrm{~m})$. 


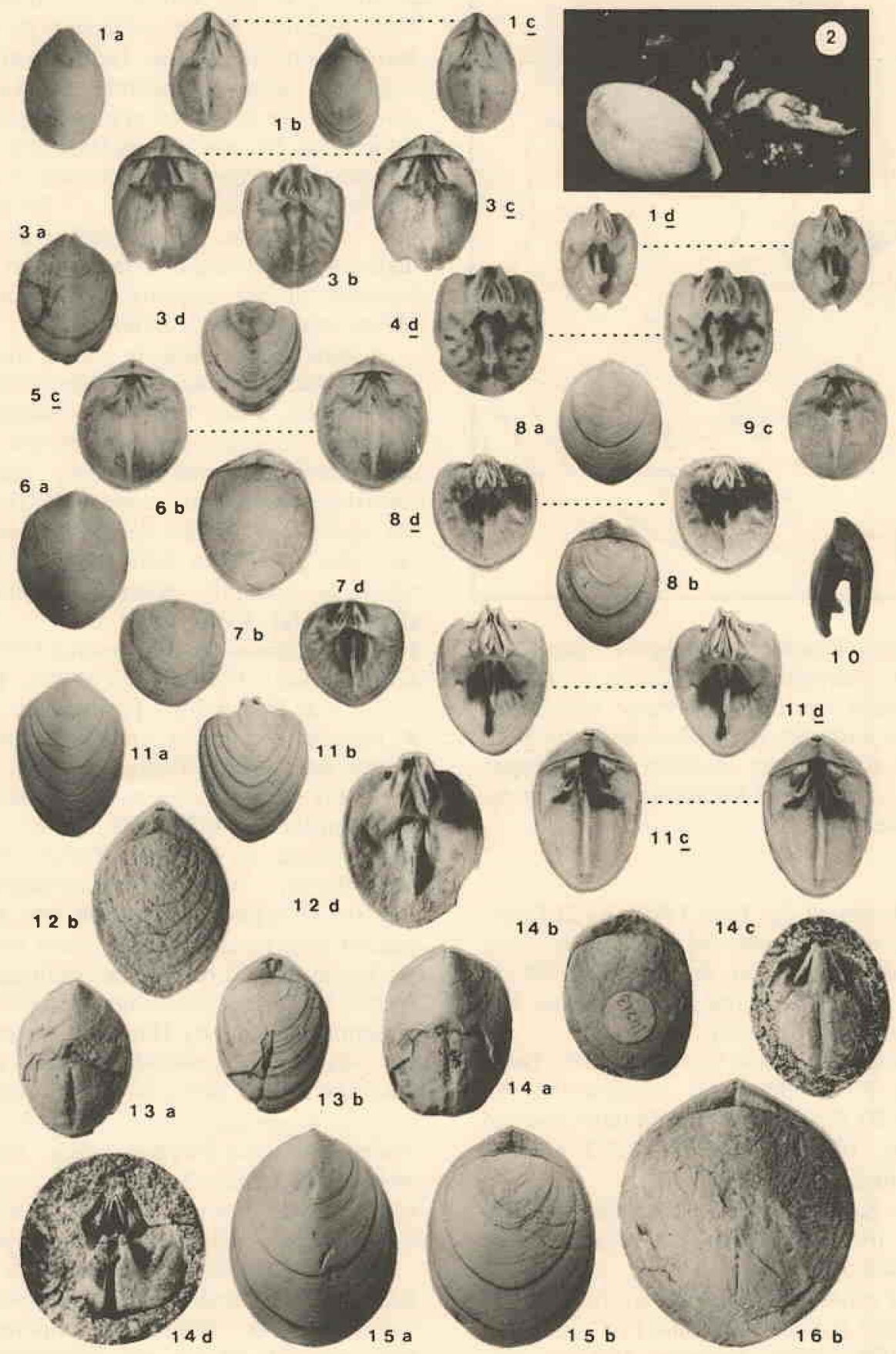

Plate 1 - Species of the genus Bouchardia. All figures magnified X 1.5 and coated (unless otherwise stated); a = external ventral view; $\mathrm{b}=$ external dorsal view; $\mathrm{c}=$ internal ventral view; $\mathbf{d}=$ internal dorsal view; underlined letters denote stereo pairs. MLP $=$ Museo de Ciencias Naturales de La Plata, Argentina. MBR $=$ Museo Argentino de Ciencias Naturales Bernardino Rivadavia, Buenos Aires, Argentina. Photos. 1-2 - B. rosea (Mawe), Recent, Brazil. 1: Rio de Janeiro (MBR Malacol. No. 20136, coll. Mello-Leitão); 2: uncoated oblique view of shell with epibionts, Itha Grande area, approx. X 2 (after Tommasi 1970, Fig. 4). 3-4 - B. transplatina Thering 1907, Entre Rios Fm., Puente Alsina, Barracas al Sud de Buenos Aires, Argentina. 3: MBR, Ihering's coll. No. 4949; 4: MBR, Ihering's coll., No. 45. 5-10 - B. zitteli Ihering 1897, Lower Patagonian (Juliense), Santa Cruz prov., Argentina. 5: Päo de Açucar (MBR, Ihering's coll. No. 44); 6-7: Patagonia (San Julian area) (MBR, Ihering's coll. No. 41); 8: Punta Cuevas (MLP No. 4796, Gaggero's coll.); 9: Manantial Salado (MBR, Ihering's coll No. 42); 10: lateral view of gaping shell, bottom of Gran Bajo de San Julian (MBR, Ihering's coll. No. 43). 11-12 - B. antarctica Buckman 1910, La Meseta Fm., Isla V. Marambio (Seymour I.), Antarctica, coll. Tonni \& Cione. 11: South of Lucila Bay (MLP No. 12919); 12: North of Penguin Bay (MLP No. 12949). 13-14 - B. sp. nov. (in Hünicken 1955), Rio Turbio Fm., Sante Cruz prov., Argentina 13: Chacra Ivovich, upper course of the Rio Turbio (MLP No. 21308); 14: Arroyo de los Corrales, Sierra Dorotea (shell, MLP No. 14213; internal moulds, MLP No. 21307). 15 - B. sp. nov. (in Brandmayr 1945), Rio Turb io Fm., Chacra Ivovich, upper course of the Rio Turbio, Santa Cruz prov., Argentina (MLP No. 21309). 16 - B. conspicua Feruglio 1935, tongue of Man Aike sandstone on top of Calafate Fm., Arroyo Calafate, on the road to Puesto Ea. 25 de Mayo, Santa Cruz prov., Argentina (MLP No. 21109, Riccardi \& Rolleri's coll.) 


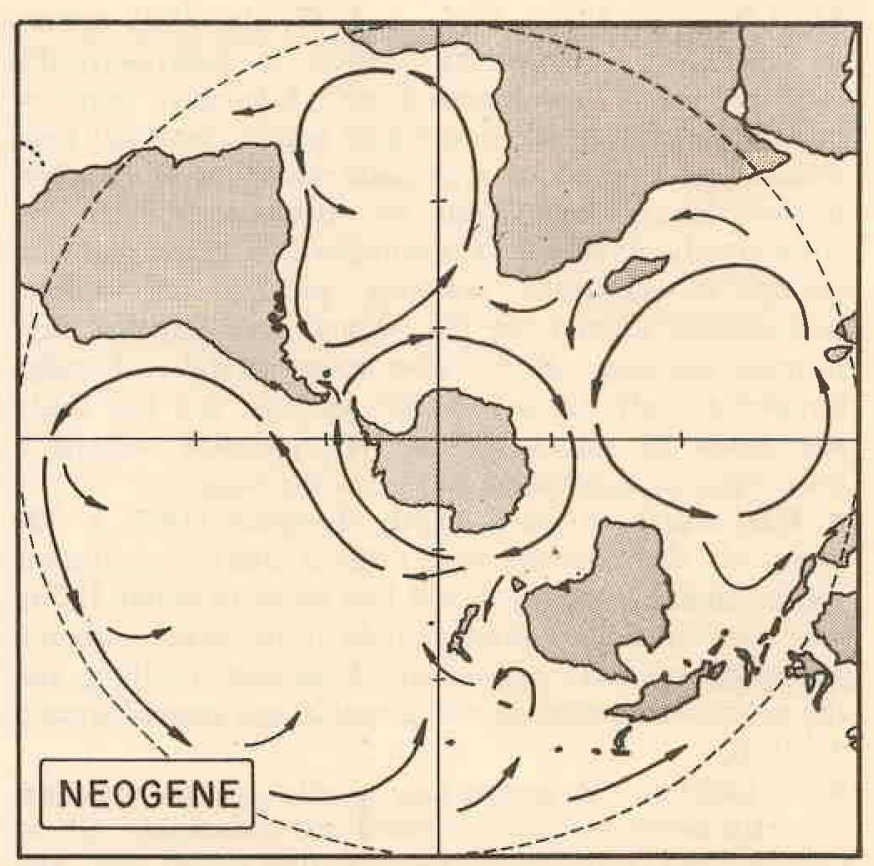

Figure 2 - Distribution of Bouchardia during the Neogene. Relative position of continents after Smith \& Briden (1977, p. 40), southern hemisphere oceanic circulation pattern compiled and tentative. Each black dot represents up to three fossiliferous localities within its radius

In all cases, the coarse, shelly, arenaceous sediments, with greenish-gray interbedded clays, are assigned to the Mesopotamian, Entrerrian or Entre Ríos Formation, traditionally regarded as Mio-Pliocene or late Miocene (Thering 1907 p. $353-354,1914$ p. 133, Feruglio 1949, II p. 219-226, Malumián 1970 p. 185-186, Camacho $1967 b$ p. $272-273$, Bertels 1979 p. $310-311$, Boltovskoy 1979 p. 374). It may be recalled in passing that undue persistent usage of a "long" Pliocene has pervaded age discussions on South American Neogene stratigraphy (cf. Hoffstetter 1980 p. 3).

- In the neighbour country of Uruguay, $B$. transplatina is known to occur in some western outcrops as well as in bore-holes far to the east. The species was already recognized by Doello-Jurado (1922 p. 198) but figured only later by Levy (1964 p. 216-218, Pl. 1, Fig. 5a-d) from Cerro Bautista, close to Arroyo de las Víboras, Nueva Palmira, and mentioned also by Frenguelli (1930 p. 30, 47) from the left bank of Río Uruguay at Punta Gorda, Colonia Department. Typical lithology consists of whitish-grayish calcareous sandstones, fine - to medium-grained, sometimes conglomeratic or even shell-beds (Francis 1975 p. 560, 568). Furthermore, it was all too briefly described by Medina (1962 p. 211) from the El Chuy drill No. 364, southernmost tip of Lagoa Mirim, at a depth of 124-125 m. See also Sprechmann (1978 p. 8-11) who characterized the interval as poorly sorted sands of fine to granule size quartz and (p. 14).

In every case, the fossiliferous strata have been invariably referred to the Entrerrian sequence, nowadays called Camacho Formation. Whilst Francis (1975 p. 560-561) still claimed a Pliocene age for this unit, it has been correlated with the Miocene by Closs \& Madeira (1968 p. 234-235), Figueiras \& Broggi (1972 p. 131-133) and
Sprechmann (1978 p. 12) according to micropalaeontological evidence.

- Several Brazilian records of Bouchardia are based on boreholes along the Pelotas Basin. On the basis of cores recovered 90 years earlier, at a depth of $93.5 \mathrm{~m}$, a Tertiary fauna was recognized and discussed by Martins (1952 text-Fig. a-b), who figured as Bouchardia cf. zitteli a brachiopod regarded by him as the most conspicuous palaeontological item, and further referred to a similar finding by Gliesch (1932), also in an artesian well from Pelotas, near $115 \mathrm{~m}$ deep. These fossils apparently occur in shellbeds associated to conglomerates and breccias bound by an argillaceous matrix. Additional occurrences have been reported from oil-industry drills bordering the Lagoas dos Patos and Mirim (located near Guaraxaim; north-east of Povo Novo; and in Ponta do Juncal).

The thick interval originally bore no formal lithostratigrafical name, yet it is obviously an equivalent, if not a lateral continuation, of the Marambaia Formation (cf. Ojeda 1982 p. 739) or the Camacho Formation (cf. Sprechmann 1978 p. 6, 12), respectively used for the southern Brazilian marginal basins and the Uruguayan portion of the Pelotas Basin. It contains various Bouchardia-bearing levels, deeper than $120 \mathrm{~m}$, consisting mainly of sandy-clayey plastic sediments greenish to gray, sometimes with a glauconitic residue, which have also furnished benthonic and planktonic foraminifera indicative of a late Miocene age (Closs 1967 p. 337-338, 1970 p. 4-6, 47-52, 55-56, Boltovskoy 1979 p. 374-375). Since such microfauna is analogous to the one from E1 Chuy, just across the border but still belonging to the same sedimentary basin, it is somewhat striking that Uruguayan Bouchardia appear easily identifiable as $B$. transplatina, whilst coetaneous ones from Brazil are allegedly more akin to $B$. zitteli. Admittedly Martins' (1952) ink drawings are not detailed enough to warrant a definitive statement regarding this issue, so the possibility of closer relationships with $B$. transplatina should be checked by means of as many specimens as possible (but is beyond the scope of this synthesis).

Recent records $\quad B$. rosea, the only extant species, with its beautiful pinkish colour (sometimes delicately striped in white), did attract the attention of European pioneer naturalists, well over 150 years ago, and so it was repeatedly depicted in several classical conchological iconographies, sometimes under the synonymous epithets tulipa or unguis. Nevertheless, it seems to have remained for long as a kind of rarity, as evidenced by special instructions that were given to the collectors of the Albatross expedition (Dall 1890 p. 232, 1920 p. 373).

Apart from early broad geographical references such as "coasts of Brazil", by and large the most typical and oft-quoted locality is Rio de Janeiro (Adams \& Adams 1858 p. $577-578$, Dall 1870 p. 142,1920 p. 373 , Davidson 1880 p. 21,1887 p. 179 , Ihering 1903 p. 338,1907 p. 471 , also PI. 1, Photo 1). Additional findings are also recorded immediately to the east of the Bay of Rio, near Cabo Frio (Dall 1890 p. 232), as well as just westwards of the Guanabara area, in the Itha Grande region (Tommasi 1970 p. 33). According to this Brazilian author the range has been confirmed along the shores of the Rio de Janeiro, and Espirito Santo States. Reported occurrences for the State of Bahia, as in the Challenger report by Davidson 


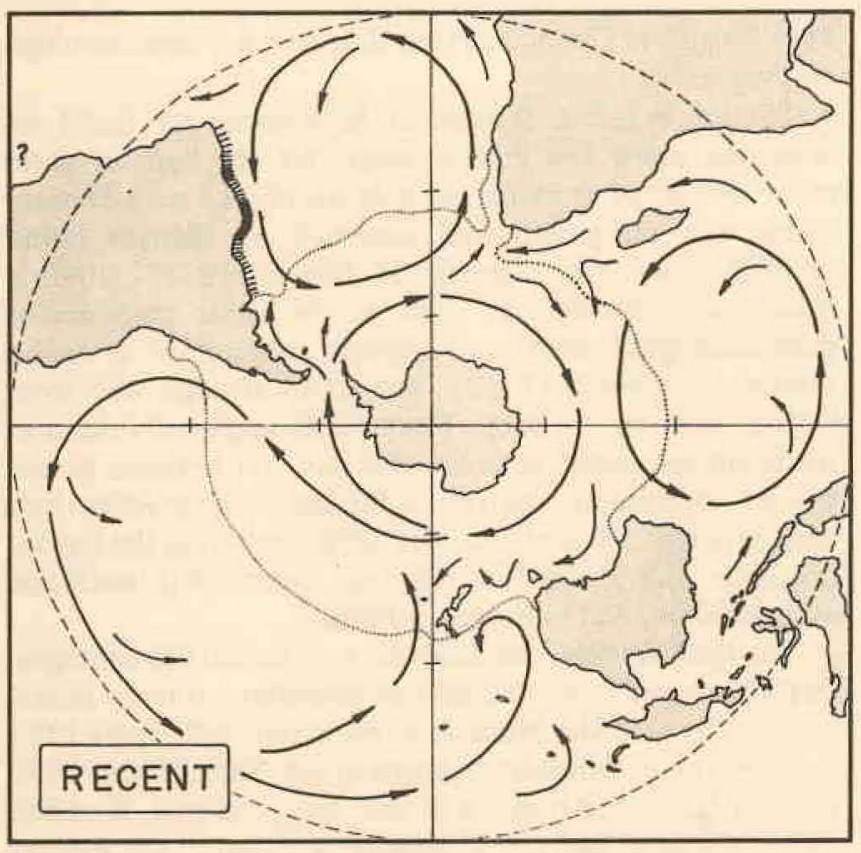

Figure 3 - Present-day distribution of Bouchardia. Base map after Smith \& Briden (1977, p. 38), with known oceanic surface circulation pattern added. The dotted line represents the $15^{\circ} \mathrm{C}$ (winter) isotherm. Most frequently reported localities denoted by denser hatching, unconfirmed record for Martinique Island, by a question mark

(1880 p. 21) and for Martinique Island or the Antilles, as in Oehlert (1887 p. 1251) and Ihering (1903 p. 338, 341) would indicate further extension towards equatorial seas. Yet, its presence in Caribbean waters seems to have fallen into oblivion, except perhaps for Martins (1952 p. 3), who relied on the same evidence. Nevertheless this was curiously omitted with no explanation in Thering's own later work (1907 p. $469-474,1914$ p. $117-148,1927$ p. $96-98)$ and would rather require further substantiation, as the sole available specimen from the Paris National Museum of Natural History which was possibly labelled by Oehlert himself unfortunately bears no provenance indication at all (d'Hondt, in litt., Dec. 1987).

On the other hand, the species range could be likewise extended southwards along the São Paulo State coasts (Ihering 1897 p. 269, 1907 p. 471) and seemingly even down to the Uruguayan shores (Dall 1920 p. 373, Zezina 1970 p. 156), although it is not at all recorded by Barattini \& Ureta (1960). It may be added in passing that material obtained by the Eugenia Expedition and housed in the Invertebrate Zoology Collection of Stockholm Natural History Museum, has been illustrated by Jaanuson (1971 p. 44-45), who cautiously reported the locality as "unknown", reluctant to accept "Singapore" as labelled.

Summing up, $B$. rosec proves to be a conspicuous element of present-day Brazilian marine benthos, having a distribution range odd enough, so as to defy a straightforward pigeonholing, and hence Zezina (1970 p. 156-157) has admitted her being unable to fit it in any of the 19 spatial ranges that she recognized for Recent brachiopods on a global scale, nor into any of the three broader "climatic zones" discerned.
ECOLOGY As far back as 1887, the living species $B$. rosea was regarded by Oehlert as bathymetrically restricted to the "Laminarian Zone". Substantial improvement in knowledge of its ecological requirements has been achieved as a result of systematic surveying of Brazilian marine faunas undertaken by Tommasi (1970). He conveniently summarized the valuable information gathered during an extensive sampling program of benthic invertebrates around the Ilha Grande and Sepetiba Bay. $B$. rosea was thus collected alive in various grab and dredge samples at only 12 out of 303 stations, and this fairly low index of success (about 4\%) probably reflects a discontinuous distribution pattern of the organism.

- With regard to water depth, Tommasi (1970 p. 33) points out that although dead shells or disarticulated valves can be found from the strand line down to about $150 \mathrm{~m}$ deep (which spans known records from earlier authors), live specimens were only obtained between $10-35 \mathrm{~m}$, and the maximum abundance of this species was centred around $18-26 \mathrm{~m}$.

- In addition, the species may qualify as steno-euhaline, since the salinity interval recorded was remarkably narrow (32.8-36.2\%), with only a single station below $35 \%$. The maximum density of living individuals (58 specimens per square meter) was reached at $35.7 \%$, and the largest average sizes were attained between $35-36 \%$ (Tommasi 1970 p. 35, Fig. 9).

- Concerning water-temperature tolerance, the highest absolute number of individuals was collected at 19.2-22.02 ${ }^{\circ} \mathrm{C}$, whereas the greatest relative abundances were achieved at $21.02-22.02^{\circ} \mathrm{C}$, and the total temperature range observed was somewhat wider $\left(19.2^{\circ} \mathrm{C}\right.$ to $\left.26.6^{\circ} \mathrm{C}\right)$ (Tommasi 1970 p. 35), whereas loose valves have been found down to about $14^{\circ} \mathrm{C}$ (Dall 1890 p. 232).

- 'In relation to substrate preferences, Tommasi's (1970 p. 40) percentage granulometric analysis of sediments from all his samples support the following generalizations:

- Live Bouchardia inhabit medium- to coarse-grained sands and even gravels, often bioclastic, but with a very low proportion of the very fine sand-coarse silt fraction and altogether lacking particles within the clay-medium silt size range. Notice that Tommasi's original wording may differ somewhat, for this results have been deliberately converted to a currently accepted granulometric scale to avoid confusion (cf. Teruggi 1982 p. 74).

- A preference for coarse-grained sediments is also suggested by the fact that maximum abundances were reached in sands containing 15 to $40 \%$ of granule-pebbly fraction $(>2 \mathrm{~mm})$ and less than $30 \%$ of $<0.5 \mathrm{~mm}$ grain-size.

- $75 \%$ of the stations providing live animals possessed a median value within the $0.5-1 \mathrm{~mm}$ grade-step (coarse sand) and the other $25 \%$ within $0.5-0.1 \mathrm{~mm}$ grade-step (medium to fine sand).

- In addition, Tommasi (1970 p. 39) has also emphasized that the distribution of the living species is also influenced by availability of food-rich sea-waters and thus greatest abundance of specimens has been observed in such places as near islands and headlands where the surrounding waters contain high concentrations of dissolved or colloidal organic nutrients, as a result of the island mass effect.

Though bottom current velocities for the actual stations were not included in Tommasi's data table, a later report for the same general area has yielded values 
of about 6 to $16 \mathrm{~cm}$ per sec. (Ikeda \& Stevenson 1980 p. 97)

- Available data on growth are essentially derived from Tommasi's (1970 p. 3841) measurements and graphs (using pedicle valve length as size indicative parameter) which revealed that:

- In studied populations, ranging from 0.6 to nearly $2 \mathrm{~cm}$, probably three successive generations were represented (cf. his Fig. 10-11).

- Statisticals calculated for all sampling stations pooled together and for each of the two richest individual stations are highly consistent, yielding average sizes between 15.06 and $16.13 \mathrm{~mm}$, which are virtually coincident with modal frequences in the order of 25-30\% (cf. his Fig. 10 and Table 2).

- Although no clear-cut relationship of average size vs. water depth was detected (cf. his Fig. 7), Tommasi maintains that larger specimens tend to occur along platform localities, whereas in coastal stations, even if abundant, they tend to be smaller (cf. his Fig. 6).

On the other hand average size shows better correlation with other ecologically significant factors, which is positive in the case of the size vs. salinity (cf. his Fig. 9), whilst with increasing degree of aggregation as well as water-temperature the inverse trend of decreasing average length is apparent (cf. his Fig. 5 and 8).

- On the basis of its peculiar shell characters, Richardson (1981 p. 93, see also Richardson \& Watson 1975a p. 382, $1975 b$ p. 386) has predicted for Bouchardia rosea a free, mobile life-style with a presumably functional pedicle: Prominent among such adaptations one can mention: overall external shape, elongate "bouchardiform" beak bearing sharp beak-ridges, specialized fused cardinalia with a deeply indented process flanked by pits for dorsal adjustor muscles, delicate dorsal median septum raised anteriorly to almost touching the ridged ventral valve, high degree of secondary internal thickening posteriorly serving as apical counterweight but leaving a long, narrow trough-like passage for the pedicle.

Such functional morphological inference is consistent with the fact that most of those very features are also present in the better-known free-living brachiopod Magadina cumingi (Davidson) from Australia. Similarly, it is not without significance that Tommasi (1970 p. 33) has reported that out of 786 live $B$. rosea no specimen was attached to any sort of substrate at all and he also provided a picture showing the way epibionts have colonized the most convex region of the ventral valve only (cf. his text-Fig. $3-4$ and Pl. 1, Photo 2 here).

\section{DISCUSSION AND CONCLUSIONS - The maps} shown (Figs. 1-3) summarize the data about Bouchardia occurrences discussed in previous sections. In addition, it was found useful to draw the tentative pattern of surface ocean circulation for the southern hemisphere as compiled and adapted from various sources (Williams et al. 1968, Kennett et al. 1974 Fig. 2a-d, Burns 1977 Fig. a-j, Boltovskoy 1979 Fig. 1, 4, Feldmann \& Zinsmeister 1984 Fig. 10a-b), as well as the July (winter) isotherm of $15^{\circ} \mathrm{C}$ $\left( \pm 60^{\circ} \mathrm{F}\right)$ which is also traced on the Recent map.

From all this information it becomes plainly evident that the latitudinal ranges of the known records of this genus reveal a conspicuous displacement in a northwards direction along the Atlantic margin of South America, from a palaeolatitude of about $75^{\circ} \mathrm{S}$ (in the Palaeogene), to about $45^{\circ} \mathrm{S}$ (in the Neogene) and eventually ending up at less than $35^{\circ} \mathrm{S}$ (in the present day).

Furthermore, the genus has not been recorded so far from certain late Tertiary to Quaternary marine brachiopod-bearing lithostratigraphic units from southern Patagonia (including Antarctica), such as the Puerto Madryn Formation, the "Cape-Fair-weather Beds", the Moby Dick Group or the Polonez Cove Formation. Hence, it seems justifiable to admit that the representatives of Bouchardia indeed underwent a long-term migration which involved occupation of new coastal territories to the north without retention of its former palaeogeographical extent in the south and can thus be qualified as a metachoresia (Termier \& Termier 1956 p. 41), whereas Martins' (1952 p. 4) "prochoretic" interpretation can be rejected.

- A reappraisal of the biogeographical significance of B. rosea according to its present-day distribution is pertinent at this point. In Zezina's (1970) world-wide systematization of Recent brachiopod zoogeographical zoning she distinguished 19 particular kinds of ranges, which allowed her to assemble them into three main groups symmetrically located relative to the Equator and reflecting broad temperature conditioning: I. cold-water species; II. warm-water species; and III. species of transitional areas (I and III were further subdivided into northern and southern hemisphere). However, as already said, Zezina failed to ascribe $B$. rosea to any of those divisions recognized by her.

On the other hand, in Oehlert's (1887 p. 1251) earlier approach, it was considered as a member of his "Caribbean Province" (which, incidentally, roughly corresponds to Zezina's "Atlantic Central-American range-type").

With the insight gained through the foregoing analysis, it seems logical that $B$. rosea either typifies a restricted range of its own (but nonetheless overlapping with Zezina's number 5) or else it can be incorporated into the Atlantic Central-American type, accordingly stretched southwards some 10 degrees further than depicted in Zezina's figure 3, specially bearing in mind that she (1970 p. 157) has conceded that a given species need not necessarily be present in every station within the range-type where it belongs.

At any rate, $B$. rosea could not be regarded as anything but a warm-water species, taking into account the ecological requirements reviewed in the previous section and the course of the $15^{\circ} \mathrm{C}$ winter isotherm which runs mostly in between the parallels $30-35^{\circ} \mathrm{S}$ and apparently confines the present-day occurrences (Fig. 3).

- In any actualistic attempt to employ the genus Bouchardia as an environmental indicator for the past, one should first check somehow its reliability, for it may be argued that it could have changed its habits during the course of its evolution since the beginning of the Cenozoic. Even though it is extremely difficult to reach absolute certainty in this respect, it can be pointed out, however, that substantial modifications in ecological requirements are more likely to be expected among generalized lineages, whereas the more specialized a stock is the less prone to have undergone such changes.

In the case of Bouchardia species, all sharing upright, sharply ridged, projecting beak; transapical epithyrid foramen; powerful, bifid cardinal process; interior of both 
valves much thickened apically; gently sulcate anterior commissure; anteriorly-raised dorsal median septum; medianly-ridged ventral valve, with straight divergent grooves for the reception of matching prominent inner socket ridges; they appear as highly specialized forms from the very start of the Tertiary (Pl. 1).

Besides, where available, taphonomic evidence does lend support to the belief that fossil species also inhabited shallow marine, medium - to coarse-grained sandy bottoms, as implied, among other things, by the remarkable similarities in the nature of the sedimentary deposits in which they are usually found. Moreover, in certain fossiliferous beds where nearly all Bouchardia specimens occur with both valves closed and unworn (sometimes also associated with bivalves preserved in their life-position) the densities of individuals noticed closely approximate those observed for living $B$. rosea $\left(12-58 / \mathrm{m}^{2}\right)$ and $M$. cumingi $\left(20-80 / \mathrm{m}^{2}\right)$.

This is not meant to imply that Bouchardia has remained absolutely unchanged through time, being obvious, for instance, that the more ancient forms attained considerably larger sizes than geologically younger ones (including extant, P1. 1). Yet, it is risky to attempt relating such long-term decrease in size to a direct effect of individual environmental conditions (such as temperature, salinity or degree of aggregation) bearing in mind that heterochronic processes may have played an important role in the evolutionary history of this genus.

- Thus granted that fossil occurrences of Bouchardia can be confidently taken as denoting the former existence of infralittoral warm-water masses, the conclusion that the shallow seas along the coasts of southern Patagonia and Antarctic Peninsula should have reached during Palaeogene times significantly warmer temperatures than those nowadays recorded in the same region, seems unavoidable.

Similarly, one can also reasonably infer that the brachiopod migration in a northwards direction which took place later in the Cenozoic reflects in fact a concomitant progressive displacement of the southern limit for such relatively high levels in water-temperature along the shores of the western South Atlantic to a more northerly location, too.

These inferences disagree with the opinion expressed by some authors such as Bordas (1957 p. 62-65), who deny that the analysis of South Atlantic marine faunas could reveal any long-term palaeoclimatic variation or trend. His point of view, however, seems to have been misleadingly influenced by his being unable to deal individually with faunistic elements that are apparently more sensitive, like Bouchardia, and by consideration of a shorter lapse of time (Pleistocene-Holocene).

- If, as interpreted in the preceding paragraphs, a lowering in water-temperature has been responsible for the latitudinal displacement of past members of the genus Bouchardia, this logically invites independently testing the envisaged scenery in the context of known geotectonic events and the palaeoceanographic consequences derived from them.

The present-day Circum-Antarctic current, transporting probably the largest volume of oceanic water (200 million $\mathrm{m}^{3} / \mathrm{sec}$ ) and mixing waters of all oceans on its complete clockwise way around Antarctica, is a major environmental factor whose paramount importance cannot be overstressed.
Sea-floor spreading studies based on palaeomagnetic anomalies and plate-tectonic theory (Barker 1970, Dalziel \& Elliot 1971, Barker \& Burrell 1977, Williams 1986) are confirmatory of the key role played by the opening of the Drake Passage between Tierra del Fuego and the Antarctic Peninsula. When this occurred, not only was the former continuity along the axis of the Andean and West Antarctic cordilleras definitively interrupted, but a complete circumpolar deep-water path was produced as well. Hence, the final barrier was removed so as to allow free oceanic Circum-Antarctic circulation, and the timing of this trascendental Mid Tertiary event has been bracketed between 20-25 Ma ago (Dalziel \& Elliot op. cit.) or between 21-26 Ma ago (Baker \& Burrell op. cit.), ie.: around the Oligocene-Miocene boundary. On the other hand, certain authors speak of a strictly Miocene opening (Ciesielski \& Wise 1977, Boltovskoy 1979) and still others date it as early as $36-41 \mathrm{Ma}$ ago, i.e.: about the Eocene-Oligocene boundary (Foster 1974).

According to results obtained under the aegis of the Deep Sea Drilling Project, Kennett et al. (1974) preferred to attribute a more decisive role to the separation of the South Tasman Rise from Victoria Land, instead. In addition to the geophysical arguments, they also stressed that a drastic modification in regional sediment pattern took place throughout the southern ocean about $25-30 \mathrm{Ma}$ ago, during the mid to late Oligocene. They invoked the onset of the Circum-Antarctic current as the primary cause for the observed change from a depositional to an erosional regime near the Palaeogene-Neogene boundary.

Anyway, this concurrent independent evidence shows a noteworthy agreement with the dissimilar distribution patterns recorded in figure 1 versus 2 and the explanatory hypothesis offered herein. The establishement of the Circum-Antarctic current system thus appears as a triggering factor capable of causing a fundamental re-arrangement of the oceanic palaeocirculation scheme, with an ensuing widespread cooling effect over the whole area, which eventually gave rise to modern climatic conditions.

This is further supported by studies on the sedimentological record, oxygen and carbon isotopic analyses, fluctuations of the carbonate compensation depth, as well as micro- and nannofossils recovered from submarine cores drilled by various research vessels in the peri-Antarctic region. In them, warmer temperatures have been deduced for Palaeocene and Eocene times (in the case of the Magellan Rise, estimated values were above $15^{\circ} \mathrm{C}$ ) and a significant drop was reported near the Eocene-Oligocene boundary. This was part of a long thermal deterioration (water temperatures remained below pre-Oligocene values) which was linked to the isolation of Antarctica from both Australia and South America, and to the development of the Antarctic ice-cap, which seemingly started already in the Oligocene and was severest in the late Miocene (e.g. Margolis et al. 1977, Ciesielski \& Wise 1977, Krasheninnikov \& Basov 1986).

In a more refined picture of the South Atlantic isotopic record, Shackleton (1986) has recently discerned within the Oligocene three intense down-peaks at $35.8 \mathrm{Ma}, 31 \mathrm{Ma}$, and $24 \mathrm{Ma}$ ago, stressing that the first one (earliest Oligocene) was the most dramatic one.

In a somewhat different but likewise relevant approach, Barron (1985) carried out a series of climate modelling 
experiments on a global scale that suggests that such Tertiary cooling episode would not represent a long-term Cenozoic trend induced by large-scale geographical changes. He favoured instead alternative explanations directly or indirectly related to plate tectonics, either as a function of variations in the atmospheric carbon dioxide concentrations due to different sea-floor spreading rates, or as a result of certain specific events such as the opening of the Drake Passage, the separation of Antarctica and Australia and the formation of the Circum-Antarctic current.

- In synthesis, the case of Bouchardia is a good example in which a causal explanation in the light of a dynamic-historical biogeographical approach is called for. From this viewpoint, the differences between the known geographical extent of the living populations with respect to those held in the past by former representatives of this warm-water genus imply a withdrawal to the north as a consequence of alterations in palaeoceanographic circulation and long-term decrease of surface water temperatures, which are consistent with prevailing ideas on the Cenozoic evolution of the South Atlantic.

Finally, the results yielded by this work can be conveniently compared with relevant contributions brought forward by other authors either from the analysis of Palaeogene and Neogene brachiopods of other southern hemisphere areas (for Australasia, see Lee 1986, MacKinnon 1987) or from the study of other taxa, within the South Atlantic, such as: Tertiary molluscs from Patagonia (Camacho 1969 p. 359-360, Ringuelet 1979 p. 261); Eocene molluscs and crustaceans from Antarctica (Zinsmeister \& Camacho 1980 p. 13, Zinsmeister 1982 p. 96-98, Feldmann \& Zinsmeister 1984 p. 1058-1059); late Cenozoic molluscs and foraminifers from Uruguay
(Sprechmann 1978 p. 54-58); Miocene to Recent foraminifers from the western South Atlantic (Boltovskoy 1979 p. 376-382) or Tertiary aquatic vertebrates from Antarctica (Cione et al. 1977 p. 16, Cione 1979 p. 195-196, Tonni \& Cione 1979 p. 78).

Acknowledgements The authors belong to the Conicet (National Research Council of Argentina) as an Investigator and a Scholar, respectively, and financial aid received for the research which led to these results is duly acknowledged.

Lic. Silvia B. Gonzáles and Ms. María Luisa Marín (National Museum of Natural Sciences B. Rivadavia, Buenos Aires) are thanked for their cooperation concerning specimens in their care.

Similarly, Dr. A.C. Riccardi (La Plata) generously put at our disposal material collected by him and offered valuable support in many ways. Dr. Mario A. Hünicken (Córdoba University) kindly gave access to unpublished information of his own. Likewise, the priceless helping hand of Dr. S.E. Damborenea was instrumental to obtaining an improved outcome in a shorter time. Assistance regarding bibliographic items was also received from Prof. D.V. Ager (Swansea, United Kingdom), Dr. D.E. Lee (Otago, New Zealand), and Lic. M.L. Aguirre (La Plata). Useful data were searched on our behalf and promptly provided by Dr. J.L. d'Hondt (Paris, France) and Mr. R. Doescher (Washington, United States of America).

The help of all these colleagues is most gratefully acknowledged.

Last but not least, thanks are also due to Dr. Miguel Uliana (Buenos Aires) for kindly undertaking the unrewarding task of delivering the oral presentation of this paper at the symposium.

\section{REFERENCES}

ADAMS, H. \& ADAMS, A. - 1858 - Class Brachiopoda. In: The genera of Recent Mollusca: arranged according to their organization. London, John van Voorst, vol. II p. 570-586; vol. III: Pl. 130-132.

BARATTINI, L.P. \& URETA, E.H. - 1960 - La fauna de las costas uruguayas del este (Invertebrados). Publ. Divulg. Cient., Mus. "D.A. Larrañaga", Conc. Dep. Montevideo, 208 p.; Lám. 1-52. Montevideo.

BARKER, P.F. - 1970 - Plate tectonics of the Scotia Sea Region. Nature, 228(5278):1293-1296. London.

BARKER, P.F. \& BURRELL, J. - 1977 - The opening of Drake Passage. Mar. Geol, 25(1-3):15-34. Amsterdam.

BARRON, E.J. - 1985 - Explanations of the Tertiary Global Cooling Trend. Palaeogeogr., Palaeoclimatol, Palaeoecol., 50(1):45-61. Amsterdam.

BERTELS, A. - 1970 - Sobre el "Piso Patagoniano" y la representación de la época del Oligoceno en Patagonia austral, República Argentina. Rev. Asoc. Geol. Argent., 25(4):495-501.

BERTELS, A. - 1975 - Bioestratigrafía del Paleógeno en la República Argentina. Rev. Esp. Micropaleontol., 7(3): 429-450.

BERTELS, A. - 1979 - Paleogeografía de los foraminíferos del Cretácico superior y Cenozoico de América del Sur. Ameghiniana, 16(3-4):273-356. Buenos Aires.

BOLTOVSKOY, E. - 1979 - Paleooceanografía del Atlántico sudoccidental desde el Mioceno, según estudios foraminiferológicos. Ameghiniana, 16(3-4):357-389. Buenos Aires.

BORDAS, A.F. - 1957 - Argumentos paleontológicos y climáticos para establecer relaciones estratigráficas del Pleistoceno-Holoceno de Argentina. Ameghiniana, 1(1-2):51-79. Buenos Aires.

BRANDMAYR, J. - 1945 - Contribución al conocimiento geológico del extremo sudsudoeste del Territorio de Santa Cruz (Región Cerro Cazador-alto Río Turbio). Bol. Inf. Petrol.,
22(255):415-437. Lám. 1-5. Buenos Aires.

BUCKMAN, S.S. - 1910 - Antarctic fossil Brachiopoda collected by the Swedish South Polar Expedition, 1901-3. Wiss. Ergeb. Schwed. Südpolar. Exped. 1901-1903, 3(7):1-43; Taf. 1-3.

BURNS, D.A. - 1977 - Major features of oceanographic development of the southeast Indian and southwest Pacific oceans interpreted from microfossil evidence. Mar. Geol., 25(1-3): 35-59.

CAMACHO, H.H. - 1967a - Invertebrados. In: BORRELLO, A.V ed. Paleontografía Bonaerense, Fascículo III. Publ. Cons. Invest. Cient. Prov. Buenos Aires (1966), 159 p.; Lám. 1-19.

CAMACHO, H.H. - 1967b - Las transgresiones del Cretácico superior y Terciario de la Argentina. Rev. Asoc. Geol. Argent., 22(4): 253-280. Buenos Aires.

CAMACHO, H.H. - 1969 - La paleogeografía patagónica y la historia del Océano Atlántico. Rev. Asoc. Geol. Argent., 24(4):357-360. Buenos Aires.

CAMINOS, R. - 1980 - Cordillera Fueguina. In: SYMPOSIO DE GEOLOGIA REGIONAL ARGENTINA, 2, Cordoba, 1980. Annales... Acad. Nac. Cienc. Córdoba. p. 1463-1501. (TURNER, J. ed.).

CARRAL TOLOSA, E.W. de - 1942 - Nota sobre los moluscos procedentes de la perforación Monte Veloz (Buenos Aires). In: CONGR. PANAM. MINAS Y GEOL., GEOL., 1, Santiago, 1942. Annales... Santiago, v. 1, n. 2, p. 562-579.

CIESIELSKI, P.F. \& WISE, S.W. - 1977 - Geologic history of the Maurice Ewing Bank of the Falkland Plateau (southwest Atlantic sector of the Southem Ocean) based on piston and drill cores. Mar. Geol., 25(1-3):175-207. 1 map. Amsterdam.

CIONE, A.L. - 1979 - Aportes paleoictiológicos al conocimiento de la evolución de las paleotemperaturas en el área austral de América del Sur durante el Cenozoico. Aspectos zoogeográficos y ecológicos conexos. Ameghiniane, 15(1-2):183-208. 
CIONE, A.L.; D'EL VALLE, R.A.; RINALDI, C.A.; TONNI, E.P. - 1977 - Nota preliminar sobre los pingüinos y tiburones del Terciario inferior de la Isla Vicecomodoro Marambio, Antártida. Contrib. Inst. Antart. Argent., 213:1-25. Buenos Aires.

CLOSS, D. - 1967 - Miocene planktonic foraminífera from southern Brazil. Micropaleontology, 13(3):337-344. New York.

CLOSS, D. - 1970 - Estratigrafia da Bacia de Pelotas, Rio Grande do Sul. Theringia ser. Geol., 3:3-75. Porto Alegre.

CLOSS, D. \& MADEIRA, M.L. - 1968 - Cenozoic Foraminifera from the Chuy drill hole, northern Uruguay. Ameghiniana, 5(7):229-236. Buenos Aires.

DALL, W.H. - 1870 - A revision of the Terebratulidae and Lingulidae, with remarks and descriptions of some Recent forms. Am. J. Conchol., 6:88-168. P1. 6-8.

DALL, W.H. - 1890 - Scientific results of explorations by the U.S. Fish Commission Steamer Albatross. No. VII. Preliminary report on the collection of Mollusca and Brachiopoda obtained in 1887-1988. Proc. U.S. Natl. Mus., 12(773):219-362. P1. 5-14. Washington.

DALL, W.H. - 1920 - Annotated list of the Recent Brachiopoda in the collection of the United States National Museum, with descriptions of thirty-three new forms. Proc. U.S. Natl. Mus., 57(2314):261-377. Washington.

DALZIEL, I.W.D. \& ELLIOT, D.H. - 1971 - Evolution of the Scotia Arc. Nature, 233(5317):246-252. London.

DAVIDSON, T. - 1850 - Sur quelques Brachiopodes nouveaux ou peu connus. Bull. Soc. Géol. France 2ème sér., 7:62-74. PL 1.

DAVIDSON, T. -1880 - Report on the Brachiopoda dredged by H.M.S. Challenger during the years 1873-1876. Rept. Sci. Results Voyage H.M.S. Challenger (1873-1876). Zoll., 1(1): 1-67. P1. 1-4. London.

DAVIDSON, T. - 1887 - A Monograph of Recent Brachiopoda. Part II. Trans. Linn. Soc. London, 2nd. Ser., Zool., 4(2): 75-182. P1. 14-25. London.

DOELLO-JURADO, M. - 1915 - Algunos moluscos marinos terciarios procedentes de un pozo surgente cerca de La Plata. Physis, 1(8):592-598. Buenos Aires.

DOELLO-JURADO, M. - 1922 - Nota preliminar sobre braquiópodos fósiles de la Argentina referidos al género Bouchardia y sobre la posición del horizonte Salamanquense. An. Soc. Cient. Argent., $94: 197-204$. Buenos Aires.

FELDMANN, R.M. \& ZINSMEISTER, W.J. - 1984 - New fossil crabs (Decapoda: Brachyura) from the La Meseta Formation (Eocene) of Antarctica: paleogeographic and biogeographic implications. J. Paleontol, 58(4):1046-1061. Tulsa, Oklahoma.

FERUGLIO, E. 1935 - Relaciones estratigráficas y faunísticas entre los estratos cretáceos y terciarios en la región del Lago Argentino y en la del Golfo de San Jorge (Patagonia). (conclusion). Bol. Inf. Petrol., 12(130):65-100. Buenos Aires.

FERUGLIO, E. - 1936/1937 - Palaeontographia patagonica. Mem. Inst. Geol. R. Univ. Padova, 11-12:1-384. Tav. 1-26. Padova.

FERUGLIO, E. - 1938 - El Cretáceo superior del Lago San Martín y de las regiones adyacentes. Physis, 12(44):293-342. Lám. $1-9$.

FERUGLIO, E. - 1944 - Estudios geológicos y glaciológicos en la región del Lago Argentino (Patagonia). Bol. Acad. Nac. Cienc., 37:3-208. Lám. 1-37. 2 maps. Córdoba.

FERUGLIO, E. - 1949 - Descripción geológica de la Patagonia. Buenos Aires, Dir. Gen. Y.P.F. (I) 334 p., lám. 1-40; (II) 349 p., lám. 41-80.

FIGUEIRAS, A. \& BROGGI, J. - 1972 - Estado actual de nuestros conocimientos sobre los moluscos fósiles del Uruguay. Parte III (Continuación). Comun. Soc. Malacol. Urug., 3(21): 131-154. Montevideo.

FOSTER, R.J. - 1974 - Eocene echinoids and the Drake Passage. Nature, 249(5459):751. London.

FRANCIS, J.C. - 1975 - Esquema bioestratigráfico regional de la República Oriental del Uruguay. In: CONGR. ARGENT. PALEONTOL. Y BIOESTRATIGR. 1, Tucumán, 1975. Actas... Tucumán. v. 2, p. 539-568.

FRENGUELLI, J. - 1930 - Apuntes de geología uruguaya. Bol. Inst. Geol. Perfor., 11:1-47. 9 lám. Montevideo.

FURQUE, G. - 1973 - Descripción Geológica de la Hoja 58 b, Lago Argentino, Provincia de Santa Cruz. Bol. Serv. Nac. Min. Geol., 140:1-51. Lám. 1-8. 1 map. Buenos Aires.

FURQUE, G. \& CAMACHO, H.H. - 1949 - El Cretácico superior de la costa Atlántica de Tierra del Fuego. Rev. Asoc. Geol.
Argent., 4(4):263-298. Lám. 1-4. Buenos Aires.

GLIESCH, R. - 1932 - Sobre a origem dos sambaquis. Egatéa, 17(14):199-207.

HATCHER, J.B. - 1900 - Sedimentary rocks of southern Patagonia. Am. J. Sci, 4th ser., 9(50):85-108. P1. 1.

HOFFSTETTER, R. - 1980 - Utilización de la escala cronoestratigráfica internacional el el Terciario mamalífero sudamericano. In: CONGR. ARGENT. PALEONTOL. Y BIOESTRATIGR. 2, CONGR. LATINOAM. PALEONTOL. 1, Buenos Aires, 1978. Actos... Buenos Aires. v. 3, p. 1-6.

HÜNICKEN, M. - 1955 - Depósitos Neocretácicos y Terciarios del extremo SSW de Santa Cruz (Cuenca Carbonífera de Río Turbío). Rev. Mus. Argent. Cienc. Nat. Buenos Aires, (Geol.), 4(1):1-164. Lám. 1-6. Buenos Aires.

IHERING, H. von - 1897 - Os molluscos dos terrenos terciários da Patagonia. Rev. Mus. Paulista, 2:217-382. Est. 3-9.

IHERING, H. von - 1903 - Les brachiopodes tertiaires de Patagonie. An. Mus Nac. Buenos Aires, 9, 3(2):321-349. Lám. 3. Buenos Aires.

IHERING, H. von - 1907 - Les brachiopodes tertiaires de l'Argentine. In: Les mollusques fossiles du Tertiaire et du Crétacé superieur de l'Argentine. An. Mus. Nac. Buenos Aires, 14, 3(7):469-481. Lám. 18. Buenos Aires.

IHERING, H. von - 1914 - Catálogo de Molluscos cretáceos e terciários da Argentina da collecção do auctor. Notos Prelim. Rev. Mus. Paulista, 1(3):6-148. Est. 1-3. São Paulo.

IHERING, H. von - 1927 - Die Geschichte des Atlantischen Ozeans. Jena, Gustav Fischer Verlag. p. 1-237. Karte 1-9.

IKEDA, Y. \& STEVENSON, M. - 1980 - Determination of circulation and short period fluctuation in Ilha Grande (RJ), Brazil. Bol. Inst. Oceanogr., 29(1):89-98. São Paulo.

JAANUSON, V. - 1971 - Evolution of the brachiopod hinge. Smithson. Contrib. Paleobiol., 3:33-46. Washington.

KENNETT, J.P.; HOUTZ, R.E.; ANDREWS, P.B.; EDWARDS, A.; GOSTIN, V.A.; HAJOS, M.; HAMPTON, M.A.; JENKINS D.G.; MARGOLIS, S.V.; OVENSHINE, A.T.; PERCH-NIELSEN, K. - 1974 - Development of Circum-Antarctic Current. Science, 186(4159):144-147.

KRASHENINNIKOV, V.A. \& BASOV, I.A. - 1986 - Late Mesozoic and Cenozoic stratigraphy and geological history of the South Atlantic High Latitudes. Palaeogeogr., Palaeoclimatol., Palaeoecol., 55(2-4):145-188. Amsterdam.

LEE, D.E. - 1986 - Paleoecology and Biogeography of the New Zealand Paleogene brachiopod Fauna. In: RACHEBOEUF, P.R. \& EMIG, C.C. eds. Les Brachiopodes fossiles et actuels. Biostratigr. Paléozoique, 4(1986):477-483. Brest.

LEVY, R. - 1964 - Acerca de los géneros Bouchardiella y Bouchardia (Braquiópodos) en el Terciario de Patagonia (Argentina). Ameghiniana, 3(7):212-220. Buenos Aires.

MacKINNON, D.I. - 1987 - The influence of Australasian-Antarctic plate tectonics and palaeoceanographic development on the morphology and inferred life habits of New Zealand Neogene brachiopods. Palaeogeogr., Palaeoclimatol., Palaeoecol., 58(1/2):63-73. Amsterdam.

MALUMIAN, N. - 1970 - Bioestratigrafía del Terciario marino del subsuelo de la Provincia de Buenos Aires (Argentina). Ameghiniana, 7(2):173-204. Buenos Aires.

MARGOLIS, S.V.; KROOPNICK, P.M.; GOODNEY, D.E. - 1977 - Cenozoic and Late Mesozoic paleoceanographic and paleoglacial history recorded in circum-Antarctic deep-sea sediments. Mar. Geol, 25(1-3):131-147. Amsterdam.

MARTINS, E.A. - 1952 - Fósseis da sondagem de 1862 em Pelotas, Estado do Rio Grande do Sul. Rio de Janeiro, Bol. Mus. Nac., Geol., n.s., 17:1-8. Rio de Janeiro.

MEDINA, N.P. de - 1962 - Notas sobre moluscos de edad entrerriana procedentes de una perforación en E1 Chuy (Dto. de Rocha, Uruguay). Rev. Mus. Argent. Cienc. Nat. B. Rivadavia, Cienc. Zool, 8(16):201-212. 1 lám. Buenos Aires.

OEHLERT, D.P. - 1887 - Brachiopodes. In: FISCHER, P. Manuel de Conchyliologie et de Paléontologie conchyliologique. Paris, Libr. F. Savy, Append. p. 1189-1334.

OJEDA, B.A.O. - 1982 - Structural framework, stratigraphy and evolution of Brazilian marginal basins. Am. Assoc. Petrol. Geol. Bull., 66(6):732-749. Tulsa.

ORTMANN, A.E. - 1902 - Tertiary Invertebrates. In: SCOTT, W.B. ed. Reports of the Princeton University Expeditions to Patagonia (1896-1899). Princeton. p. 45-332. Pl. 11-39. (Vol. IV, Palaeontology I, Part II). 
OWEN, E.F. - 1980 - Tertiary and Cretaceous brachiopods from Seymour, Cockburn and James Ross Islands, Antarctica. Bull. Brit. Mus. (Nat. Hist.), Geol., 33(2):123-145. London.

RICCARDI, A.C. \& ROLLERI, E.O. - 1980 - Cordillera Patagónica Austral. In: TURNER, J. ed. Segundo Simposio de Geología Regional Argentina II. Acad. Nac. Cienc. Córdoba. p. 1173-1306.

RICHARDSON, J.R. - 1973 - Studies on Australian Cainozoic brachiopods. 3. The Subfamily Bouchardiinae (Terebratellidae). Proc. R. Sac. Victoria, 86(1):127-132. P1. 7. Melbourne.

RICHARDSON, J.R. - 1981 - Brachiopods and pedicles. Paleobiology, 7(1):87-95. Chicago.

RICHARDSON, J.R. \& WATSON, J.E. - 1975a - Locomotory adaptations in a free-lying brachiopod. Science, 189(4200): 381-382.

RICHARDSON, J.R. \& WATSON, J.E. - 1975b - Form and function in a recent free living brachiopod Magadina cumingi. Paleobiology, 1(4):379-387. Chicago.

RIGGI, J.C. - 1978 - La importancia de los sedimentos piroclásticos y de la sílice biogenética en la estratigrafía de la Formación Patagonia. Rev. Asoc. Geol Argent., 33(2):158-171. Buenos Aires.

RIGGI, J.C. - 1979 - Nuevo esquema estratigráfico de la Formación Patagonia. Rev. Asoc. Geol. Argent. 34(1):1-11. Buenos Aires.

RINGUELET, R.A. - 1979 - Dinamismo histórico de la fauna brasílica en la Argentina. Ameghiniane, 15(1-2):255-262. Buenos Aires.

SHACKLETON, N.J. - 1986 - Paleogene Stable Isotope Events. Palaeogeogr., Palaeoclimatol, Palaeoecol., 57.(1):91-102.

SMITH, A.G. \& BRIDEN, J.C. - 1977 - Mesozoic and Cenozoic Paleocontinental Maps Cambridge Univ. Press. 63 p. Cambridge.

SPRECHMANN, P. - 1978 - The paleoecology and paleogeography of the Uruguayan coastal area during the Neogene and Quaternary. Zitteliana, 4:3-72. Taf. 1-6. München.

SUESS, E. - 1860 - Remarks on the distribution of the Brachiopoda. The Geologist, 3:285-293. London.

TERMIER, H. \& TERMIER, G. - 1956 - La notion de migration en paléontologie. Geol. Rundsch., 45(1):26-42. Stuttgart.

TERUGGI, M.E. - 1982 - Diccionario Sedimentológico: Volumen
I: rocas clásticas y piroclásticas. Buenos Aires, Edic. Cient. Argent. Librart. 104 p.

THOMSON, J.A. - 1918 - The genus Bouchardia (Brachiopoda) and the age of the Younger Beds of Seymour Island, West Antarctica. Geol. Mag., 55(6):258-263. London.

TOMMASI, L.R. - 1970 - Sobre o braquiópode Bouchardia rosea (Mawe, 1823). Bol. Inst. Oceanogr., 19:33-42. São Paulo.

TONNI, E.P. \& CIONE, A.L. - 1979 - Una nueva colección de vertebrados del Terciario inferior de la isla Vicecomodoro Marambio (Seymour Island), Antártida. Obre Cent. Mus La Plata 5, Paleontol., p. 73-79. La Plata.

WILLIAMS, C.A. - 1986 - An oceanwide view of Palaeogene plate tectonic events. Palaeogeogr., Palaeoclimatol., Palaeoecol., 57(1):3-25. Amsterdam.

WILLIAMS, J.; HIGGINSON, J.J.; ROHRBOUGH, J.D. - 1968 Oceanic surface currents. In: PIRIE, R.G. ed. Oceanography. Contemporary readings in ocean sciences. London, Oxford University Press (1973). p. 99-107.

WINDHAUSEN, A. - 1931 - Geología Argentina. Segunda parte: Geología histórica y regional del territorio argentino. Buenos Aires, J. Peuser. 646 p.; 58 lám. 1 map.

ZEZINA, O.N. - 1970 - Brachiopod distribution in the Recent Ocean with reference to problems of zoogeographic zoning. Paleontol. J., 4(2):147-160 (= Paleontol. Zhurn. 1970(2): 3-17).

ZINSMEISTER, W.J. - 1981 - Middle to Late Eocene invertebrate fauna from the San Julian Formation at Punta Casamayor, Santa Cruz Province, southern Argentina. J. Paleontol., 55(5): 1083-1102. Tulsa.

ZINSMEISTER, W.J. - 1982 - Late Cretaceous-Early Tertiary molluscan biogeography of the southem Circum-Pacific. J. Paleontol., 56(1):84-102. Tulsa.

ZINSMEISTER, W.J. \& CAMACHO, H.H. - 1980 - Late Eocene Struthiolariidae (Mollusca: Gastropoda) from Seymour Island, Antarctic Peninsula, and their significance to the biogeography of Early Tertiary shallow-water faunas of the southern hemisphere. J. Paleontol., 54(1):1-14. Tulsa.

MANUSCRITO 496

Recebido em 24 de setembro de 1987 Revisão aceita em 2 de fevereiro de 1988 